\title{
Reaction of $\beta$-Alkoxyvinyl Halomethyl Ketones with Cyanoacetohydrazide
}

\author{
Marcos A. P. Martins, * Dayse N. Moreira, Clarissa P. Frizzo, Kelvis Longhi, \\ Nilo Zanatta and Helio G. Bonacorso
}

Departamento de Química, Universidade Federal de Santa Maria, 97105-900 Santa Maria-RS, Brazil

\begin{abstract}
Este trabalho apresenta a síntese de uma série de treze 1-cianoacetil-5-hidroxi-5-halometil1H-4,5-diidropirazóis a partir da reação de condensação entre cianoacetohidrazida e 4-alcoxi-3alquen-2-onas $\left[\mathrm{R}^{3} \mathrm{C}(\mathrm{O}) \mathrm{C}\left(\mathrm{R}^{2}\right)=\mathrm{C}\left(\mathrm{R}^{1}\right)(\mathrm{OR})\right.$, onde $\mathrm{R}^{3}=\mathrm{CF}_{3}, \mathrm{CCl}_{3}, \mathrm{CHCl}_{2}, \mathrm{CO}_{2} \mathrm{Et} ; \mathrm{R}^{2}=\mathrm{H}, \mathrm{Me} ; \mathrm{R}^{1}=$ $\mathrm{H}, \mathrm{Me}, \mathrm{Et}, \mathrm{Pr}$, Pentil, c-Hexil, Ph, e R = Me, Et]. Reações de desidratação e derivatização destes compostos também são apresentadas com o objetivo de demonstrar a versatilidade de pirazóis 1-cianoacetil-substituídos como blocos precursores em síntese orgânica.
\end{abstract}

The synthesis of thirteen 1-cyanoacetyl-5-hydroxy-5-halomethyl-1H-4,5-dihydropyrazoles from the reaction of 4-alkoxy-3-alken-2-ones $\left[\mathrm{R}^{3} \mathrm{C}(\mathrm{O}) \mathrm{C}\left(\mathrm{R}^{2}\right)=\mathrm{C}\left(\mathrm{R}^{1}\right)(\mathrm{OR})\right.$, where $\mathrm{R}^{3}=\mathrm{CF}_{3}, \mathrm{CCl}_{3}$, $\mathrm{CHCl}_{2}, \mathrm{CO}_{2} \mathrm{Et} ; \mathrm{R}^{2}=\mathrm{H}, \mathrm{Me} ; \mathrm{R}^{1}=\mathrm{H}, \mathrm{Me}$, Et, Pr, Pentyl, c-Hexyl, Ph, and R = Me, Et] with cyanoacetohydrazide is reported. In order to show the versatility of using the 1-cyanoacetylsubstituted pyrazoles as important building blocks in organic synthesis, some attempts to obtain pyrazole derivatives also are described.

Keywords: pyrazoline, enones, cyanoacetohydrazide, cyclocondensation

\section{Introduction}

Among several commercially available substituted hydrazines, cyanoacetic acid hydrazide has received the most attention recently. ${ }^{1}$ Cyanoacetic acid hydrazide is a versatile and convenient intermediate for the synthesis of wide variety of heterocyclic compounds. This substrate can act as an ambident nucleophile, that is, as both an $\mathrm{N}$ - and a $\mathrm{C}$-nucleophile. Upon treatment of cyanoacetic acid hydrazide with various reactants, the attack can take place at five possible sites; the nucleophile is able to attack the carbon atom of the carbonyl group (position-3) and the carbon atom of the nitrile function (position-5). In addition, the carbon atom of the active methylene group (position-4) and the nitrogen atoms of the hydrazine portion (position-1 and position-2) are able to attack electrophiles (Scheme 1). The reactions of cyanoacetic acid hydrazide with numerous reactants (nucleophiles and electrophiles) are used in the synthesis of a variety of polyfunctional heterocyclic compounds of biological interest. ${ }^{1}$ The main reaction reported involves the cyclocondensation reaction of cyanoacetic acid hydrazide with 1,3-dicarbonyl compounds. It has been demonstrated in the literature that the product of this cyclocondensation

*e-mail: mmartins@base.ufsm.br reaction is dependent on the reaction conditions. ${ }^{1}$ The results obtained reveal that there is a delicate compromise between the reaction conditions, starting materials and products formed. In general, when the cyanoacetic acid hydrazide and 1,3-dicarbonyl compounds or $\alpha, \beta$-unsaturated systems (such as [aryl]alkylidenemalononitrile, cyanobutanoates) were refluxed in ethanol containing a catalytic amount of base, a pyridone was obtained..$^{2-5}$ On the other hand, their treatment with a catalytic amount of concentrated $\mathrm{HCl}$ at room temperature afforded a pyrazole (Scheme 1). ${ }^{6-8}$

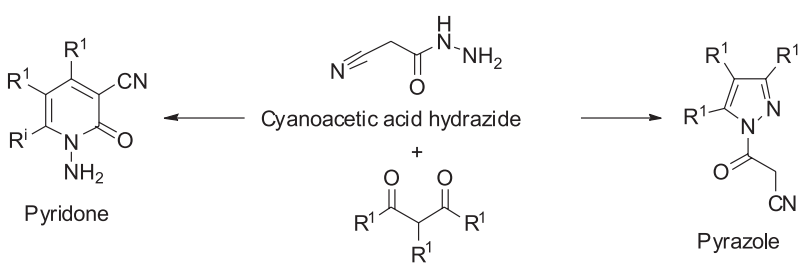

Scheme 1.

Alternatively, when $\alpha, \beta$-unsaturated ketones and $\beta$-ketoaldehyde were reacted with cyanoacetic acid hydrazide under basic conditions, pyrazolopyrimidines were formed. In addition, for 1,3-dicarbonyl compounds, when acetic acid was employed instead of concentrated $\mathrm{HCl}$, pyrazolopyrimidin-2-ols were obtained. ${ }^{9,10}$ 
Data from the literature have demonstrated that the most convenient method to construct halomethylated hetero-cycles is from halomethyl-containing building blocks as starting reactants. ${ }^{11-14}$ Over the last few years, our re-search group has reported the synthesis and the importance of $\beta$-alkoxyvinyl halomethyl ketones. ${ }^{11,12}$ This compounds are versatile building blocks used in the construction of halomethyl-heterocyclic rings. ${ }^{11-16} \mathrm{We}$ have developed a general procedure for preparing $\beta$-alkoxyvinyl halomethyl ketones from the $\beta$-haloacetylation of enol ethers using functionalized acyl groups $\mathrm{CX}_{3} \mathrm{CO}$ (with $\mathrm{X}=\mathrm{F}$ and $\mathrm{Cl}) .{ }^{11,12}$ Over time, we have demonstrated that these compounds are of general interest as building blocks for a variety of trihalomethylated heterocycles, e.g., isoxazoles, pyrazoles, pyrazolium chlorides, pyrrolidinones, pyrimidines, pyrimidinones, pyridines, thiazolopyrimidinones, selenazoles, quinolines and diazepines. $^{12,13}$ Thus, considering: (i) the high reactional versatility of the building blocks, $\beta$-alkoxyvinyl halomethyl ketones and cyanoacetic acid hydrazide; (ii) the regioselectivity afforded by $\beta$-alkoxyvinyl halomethyl ketones in the cyclocondensation reactions; ${ }^{12,13}$ and (iii) the delicate compromise between cyanoacetic acid hydrazide reaction conditions and the product formed, we decided to study the reaction between $\beta$-alkoxyvinyl halomethyl ketones and cyanoacetic acid hydrazide.

\section{Results and Discussion}

The enones 1-4 (Scheme 2) were synthesized from the reaction of the respective acyl chloride or anhydride with enol ether or acetal, in accordance with the methodology developed in our laboratory. ${ }^{12}$ Cyanoacetic acid hydrazide was obtained commercially. We started our study from the reaction of enone $\mathbf{1 b}$ with cyanoacetic acid hydrazide by evaluating the best reaction conditions (Table 1).

The first reaction condition evaluated was based on a report from the literature, in which the authors synthesized pyrazoles from 1,3-dicarbonyl compounds. ${ }^{17}$ However, for the synthesis we used, two hours were not enough to obtain the 4,5-dihydropyrazole $\mathbf{5} \mathbf{b}$ and the starting material remained in part, unchanged (entry 1). However, in 3 hours the conversion to the expected 4,5-dihydropyrazole (5b) was completed with $80 \%$ yield (entry 2 ). When reflux was employed, under the same reaction conditions, in 2 hours, the formation of 3-methyl-5-trifluoromethyl-1 $H$-pyrazole (9b, see Scheme 5) from the loss of the cyanoacetyl group was detected (entry 3). The use of ethanol as solvent without $\mathrm{HCl}$ led to an increase in the reaction time, and in 16 hours at room temperature the 4,5-dihydropyrazole $\mathbf{5 b}$ was also obtained with $80 \%$ yield (entry 4 ). The addition of a catalytic amount of conc. $\mathrm{HCl}$ resulted in a mixture of pyrazoles, $\mathbf{5 b}$ and $\mathbf{9 b}$ (entry 5). When reflux was used under these conditions, the ratio of $\mathbf{5 b} \mathbf{b} \mathbf{9 b}$ was reduced (entry 6). On the other hand, when the reaction was performed under basic conditions $(\mathrm{KOH})$, while pyridone derivatives were expected, surprisingly, pyrazole 9b was obtained, although in low yield (entry 7). The reactions performed in piperidine led to reduced yields of the products (entries $8,9)$. However, when pyridine was used, $\mathbf{5} \mathbf{b}$ was formed as the main product, but in low yields (entries 10,11). Furthermore, the results found in the Table 1 show that for all the reaction conditions tested, pyrazoles $\mathbf{5 b}$ or $\mathbf{9 b}$ were the only products formed. These results indicate that trihalomethylated $\alpha, \beta$-unsaturated ketones always reacted with cyanoacetic acid hydrazide to form pyrazoles, different from those products described in the literature where 1,3-dicarbonyl compounds, alkylidenemalononitriles and

Table 1. Reaction conditions of enone $\mathbf{1 b}$ with cyanoacetic acid hydrazide

\begin{tabular}{|c|c|c|c|c|c|c|}
\hline Entry & time $/ \mathrm{h}$ & Solvent & Temperature $/{ }^{\circ} \mathrm{C}$ & Acid/Base & Product molar ratio $\mathbf{5 b}: \mathbf{9} \mathbf{b}^{\mathrm{a}}$ & Yield / (\%) \\
\hline 1 & 2 & $\mathrm{H} 2 \mathrm{O}$ & r.t & $\mathrm{HCl}$ & $3: 1$ & 60 \\
\hline 2 & 3 & $\mathrm{H} 2 \mathrm{O}$ & r.t. & $\mathrm{HCl}$ & $1: 0$ & 80 \\
\hline 3 & 2 & $\mathrm{H} 2 \mathrm{O}$ & reflux & $\mathrm{HCl}$ & $0: 1$ & 75 \\
\hline 4 & 16 & $\mathrm{EtOH}$ & r.t. & - & $1: 0$ & 80 \\
\hline 5 & 1 & $\mathrm{EtOH}$ & r.t. & $\mathrm{HCl}$ & $15: 1$ & 48 \\
\hline 6 & 1 & $\mathrm{EtOH}$ & reflux & $\mathrm{HCl}$ & $7: 1$ & 50 \\
\hline 7 & 16 & EtOH & r.t. & $\mathrm{KOH}$ & $0: 1$ & 30 \\
\hline 8 & 16 & $\mathrm{EtOH}$ & r.t. & Piperidine & $1: 3$ & 20 \\
\hline 9 & 16 & $\mathrm{EtOH}$ & reflux & Piperidine & $0: 1$ & 5 \\
\hline 10 & 16 & $\mathrm{EtOH}$ & r.t. & Py & $1: 0$ & 60 \\
\hline 11 & 16 & $\mathrm{EtOH}$ & reflux & Py & $30: 1$ & 46 \\
\hline
\end{tabular}




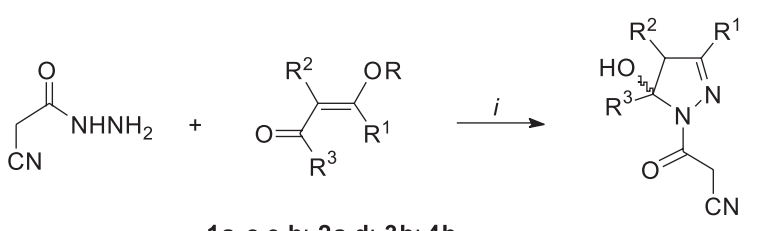

1a-c,e-h; 2a-d; 3b; 4b 5a-c,e-h; 6a-d; 7b; 8b

i: $\mathrm{H}_{2} \mathrm{O}, \mathrm{HCl}$, r.t., $3-8 \mathrm{~h}$

\begin{tabular}{cccccccc}
\hline Reactant & $\mathrm{R}$ & $\mathrm{R}^{3}$ & $\mathrm{R}^{2}$ & $\mathrm{R}^{1}$ & Product & time $/ \mathrm{h}$ & ${\text { Yield } /(\%)^{\mathrm{a}}}^{2}$ \\
\hline $\mathbf{1 a}$ & $\mathrm{Et}$ & $\mathrm{CF}_{3}$ & $\mathrm{H}$ & $\mathrm{H}$ & $\mathbf{5 a}$ & 3 & 90 \\
$\mathbf{1 b}$ & $\mathrm{Me}$ & $\mathrm{CF}_{3}$ & $\mathrm{H}$ & $\mathrm{Me}$ & $\mathbf{5 b}$ & 3 & 80 \\
$\mathbf{1 c}$ & $\mathrm{Me}$ & $\mathrm{CF}_{3}$ & $\mathrm{H}$ & $\mathrm{Et}$ & $\mathbf{5 c}$ & 3 & 70 \\
$\mathbf{1 e}$ & $\mathrm{Me}$ & $\mathrm{CF}_{3}$ & $\mathrm{H}$ & $\mathrm{Pentyl}$ & $\mathbf{5 e}$ & 3 & 85 \\
$\mathbf{1 f}$ & $\mathrm{Me}$ & $\mathrm{CF}_{3}$ & & $-\left(\mathrm{CH}_{2}\right)_{4}-$ & $\mathbf{5 f}$ & 3 & 66 \\
$\mathbf{1 g}$ & $\mathrm{Me}$ & $\mathrm{CF}_{3}$ & $\mathrm{H}$ & $\mathrm{Ph}$ & $\mathbf{5 g}$ & 3 & 76 \\
$\mathbf{1 h}$ & $\mathrm{Et}$ & $\mathrm{CF}_{3}$ & $\mathrm{Me}$ & $\mathrm{H}$ & $\mathbf{5 h}$ & 3 & 70 \\
$\mathbf{2 a}$ & $\mathrm{Et}$ & $\mathrm{CCl}_{3}$ & $\mathrm{H}$ & $\mathrm{H}$ & $\mathbf{6 a}$ & 8 & 65 \\
$\mathbf{2 b}$ & $\mathrm{Me}$ & $\mathrm{CCl}_{3}$ & $\mathrm{H}$ & $\mathrm{Me}$ & $\mathbf{6 b}$ & 8 & 90 \\
$\mathbf{2 c}$ & $\mathrm{Me}$ & $\mathrm{CCl}_{3}$ & $\mathrm{H}$ & $\mathrm{Et}$ & $\mathbf{6 c}$ & 8 & 90 \\
$\mathbf{2 d}$ & $\mathrm{Me}$ & $\mathrm{CCl}_{3}$ & $\mathrm{H}$ & $\mathrm{Pr}$ & $\mathbf{6 d}$ & 8 & 80 \\
$\mathbf{3 b}$ & $\mathrm{Me}$ & $\mathrm{CHCl}_{2}$ & $\mathrm{H}$ & $\mathrm{Me}$ & $\mathbf{7 b}$ & 8 & 54 \\
$\mathbf{4 b}$ & $\mathrm{Me}$ & $\mathrm{CO}_{2} \mathrm{Et}$ & $\mathrm{H}$ & $\mathrm{Me}$ & $\mathbf{8 b}$ & 8 & 75 \\
\hline
\end{tabular}

Scheme 2.

cyanobutanoates reacted with this same reactant. Based on the results shown in the Table 1, we developed an efficient general method to produce the 4,5-dihydropyrazoles 5-8 (Scheme 2). Thus, the cyclocondensation reactions were performed in water as solvent with a catalytic amount of concentrated $\mathrm{HCl}$, with a reaction time of 3 hours (to obtain products 5) or 8 hours (to obtain products 6-8) at room temperature, and a series of 1-cyanoacetyl-5-hydroxy-5halomethyl-1 $H$-4,5-dihydropyrazoles 5-8 was obtained in reasonable to good yields (Scheme 2).

Although the 4,5-dihydropyrazoles 5a-c,f-g are commercially available, however, their synthesis and spectral characterization are not reported in literature. 4,5-Dihydropyrazoles 5-8 showed sets of ${ }^{1} \mathrm{H}$ and ${ }^{13} \mathrm{C}$ NMR data that correspond to the proposed structures. Compounds 5a-c,e-g, 6a-d, $7 \mathbf{b}$ and $\mathbf{8 b}$ showed ${ }^{1} \mathrm{H}$ NMR chemical shifts of the diastereotopic methylene protons (H-4a and $\mathrm{H}-4 \mathrm{~b}$ ) as a characteristic $\mathrm{AB}$ system and as a doublet at the range of $\delta$ 3.26-3.70, respectively, with a geminal coupling constant at the range of ${ }^{2} J 18-20 \mathrm{~Hz}$. The same compounds showed the ${ }^{13} \mathrm{C}$ NMR spectra with typical chemical shifts of 4,5-dihydro- $1 H$-pyrazole rings at the ranges of $\delta 146.8$ 163.6 (C-3), 42.7-53.4 (C-4), 90.1-92.5 (C-5, 5), 100.0101.7 (C-5, 6), 72.3 (C-5, 7), 87.8 (C-5, 8), 122.1-123.6 $\left(\mathrm{CF}_{3}\right), 101.2-106.9\left(\mathrm{CCl}_{3}\right), 96.0\left(\mathrm{CHCl}_{2}\right), 159.8\left(\mathrm{CO}_{2} \mathrm{Et}\right)$. Although the attainment of two pairs of diastereoisomers for compounds $\mathbf{5 f}$ and $\mathbf{5 h}$ was expected from the synthetic procedure, the ${ }^{1} \mathrm{H}$ and ${ }^{13} \mathrm{C}$ NMR data of these compounds showed that only one pair of diastereoisomers was obtained. Semi-empirical AM1 calculations ${ }^{18}$ showed that the diastereoisomer pair $3 \mathrm{R} 3 \mathrm{aS} / 3 \mathrm{~S} 3 \mathrm{aR}$ of $\mathbf{5 f}$ compound was $1.12 \mathrm{kcal} \mathrm{mol}^{-1}$ more stable than the diastereoisomer pair
3S3aS/3R3aR and the diastereoisomer pair 4S5R/4R5S of compound $\mathbf{5 h}$ was $1.48 \mathrm{kcal} \mathrm{mol}^{-1}$ more stable than the diastereoisomer pair $4 \mathrm{R} 5 \mathrm{R} / 4 \mathrm{~S} 5 \mathrm{~S}$. These data are supported by previously reported crystallographic studies for analogous compounds. ${ }^{19}$ The difference in energy between the two pairs of diastereoisomers for compounds $\mathbf{5 f}$ and $\mathbf{5 h}$ indicates that the preferable formation of the diastereoisomer pair (>90\%) of compounds is that where the hydroxyl and methylene group (5f) and/or methyl group (5h) are situated cis to each other. The structure of compound $\mathbf{5 f}$ was also confirmed by crystal X-ray diffraction (Figure 1). ${ }^{20}$

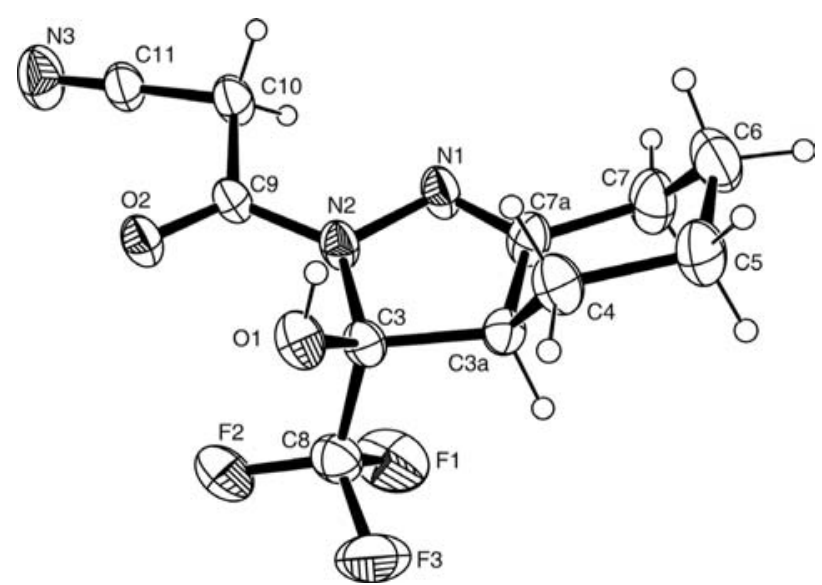

Figure 1. ORTEP obtained from crystal structure of $3,3 a, 4,5,6,7-$ hexahydro-3-trifluoromethyl-3-hydroxy-[2,1]-benzocyanoacetyl pyrazole (5f).

The mechanism of formation of 4,5-dihydropyrazoles involves a cyclocondensation reaction, which is depict in Scheme 3. The reaction proceeds by a Michael addition/ 
elimination on the $\beta$-carbon atom of the enone ${ }^{21}$ by the more nucleophilic function of the cyanoacetic acid hydrazide. The enaminoketone intermediate formed undergoes cyclization by the addition of a second $\mathrm{NH}$ function to the carbonyl carbon to provide 4,5-dihydropyrazoles 5-8.

During the study of the reaction between enones 1 and cyanoacetic acid hydrazide, we found that a small increase in the reaction temperature $\left(50^{\circ} \mathrm{C}\right)$ resulted in elimination of water, with simultaneous loss of the cyanoacetyl group and the subsequent formation of 3-methyl-5-trifluoromethyl$1 H$-pyrazole (9b). In previous studies, we had obtained similar trihalomethylated 4,5-dihydropyrazoles containing a strong electron-withdrawing group attached to the N1atom, where it was possible to eliminate a water molecule and to obtain the aromatic pyrazole without the loss of the N1-group, ${ }^{14,22}$ by stirring the reaction mixture in ethanol, for 24 hours, at $45^{\circ} \mathrm{C}$. To obtain the $1 \mathrm{H}$-pyrazole a subsequent step was necessary, which involved the use of reflux in the presence of sulphuric acid for 4 hours. ${ }^{14,22}$ Thus, we decided to investigate the possibility of dehydrating 4,5-dihydropyrazoles 5 to obtain the aromatic 1-cyanoacetylpyrazoles. In Table 2 the attempts of dehydratation are described.
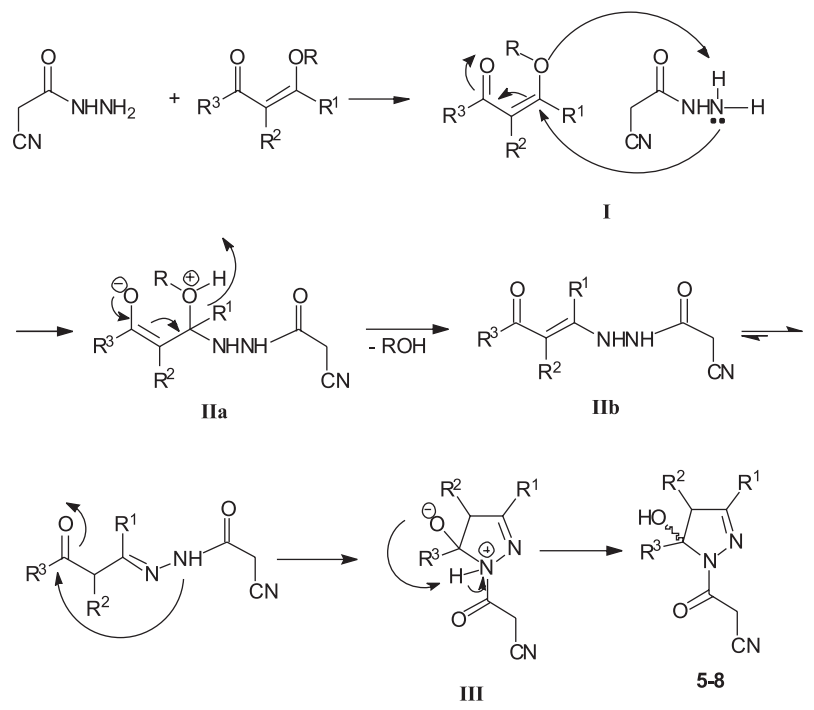

Scheme 3.

Table 2. Reaction conditions for dehydratation of cyanoacetyl pyrazoline $5 \mathbf{b}$

\begin{tabular}{lllll}
\hline Entry & time/h & $\mathrm{T} /{ }^{\circ} \mathrm{C}$ & Solvent & Acid/Base \\
\hline 1 & 16 & 50 & EtOH & - \\
2 & 16 & 50 & EtOH & Piperidine \\
3 & 1 & Reflux & Benzene & $\mathrm{SOCl}_{2} / \mathrm{Py}$ \\
4 & 4 & 50 & $\mathrm{CH}_{2} \mathrm{Cl}_{2}$ & $\mathrm{AcOH}$ \\
\hline
\end{tabular}

In a strategy for dehydratation of $\mathbf{5 b}$ acetic acid and dichloromethane as solvent were used, but only the starting material was recovered. In another attempt, with sulfonyl chloride, pyridine and benzene as solvent, we observed 3-methyl-5-trifluoromethyl-1H-pyrazole (9b) as a single product. Therefore, we understood that our attempts of dehydratation of 4,5-dihydropyrazole $\mathbf{5 b}$ were unsuccessful since the acetic acid conditions were mild while the sulfonyl chloride conditions were harsh. The formation of product 9b can be explained through the mechanism showed in Scheme 4.
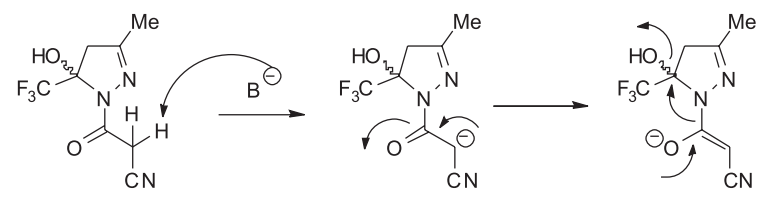

$5 b$
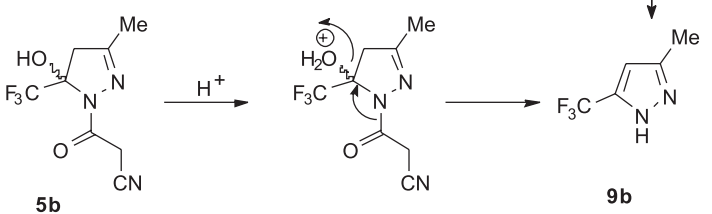

Scheme 4.

When the base catalyst was used, the carbanion was obtained and than, from the ketene elimination, the NHpyrazole was formed. However, when acidic catalyst was used, the pyrazole formation occurred through dehydratation and acyl cation elimination.

The scope of this work are not limited to synthesis of 4,5-dihydropyrazoles from the cyclocondensation of cianoacetohydrazide and halomethylated $\alpha, \beta$-unsaturated ketones. But it was broad to derivate of these compounds. Thus, with the objective of showing the importance of this heterocycle as new precursor and considering that pyrazoles contain poli-functionalized substituents, we decided react the 1-cyanoacetyl-portion of product $\mathbf{5} \mathbf{b}$ with dimethylformamide dimethyl acetal (DMFDMA). The condensation reaction of $\mathbf{5 b}$ with DMFDMA was carried out in solvent free conditions, at $50{ }^{\circ} \mathrm{C}$, with a reaction time of 2 hours (Scheme 5).

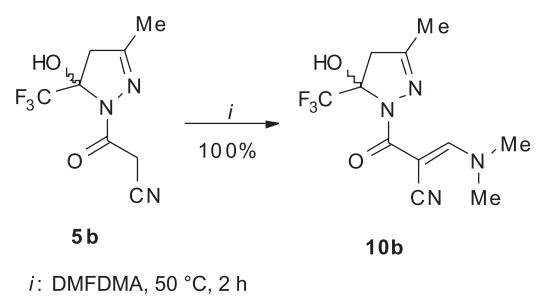

Scheme 5. 
All the isolated products were well characterized by their melting points, ${ }^{1} \mathrm{H}$ and ${ }^{13} \mathrm{C} \mathrm{NMR}$, and MS spectral data (see Experimental section).

\section{Conclusions}

In summary, we demonstrated that the products obtained from the reaction of cyanoacetic acid hydrazide with trihalomethylated $\alpha, \beta$-unsaturated ketones were different from those described in the literature for similar 1,3-dielectrophile substrates. In addition, we developed an efficient and regiospecific preparation of 1-cyanoacetyl-5halomethyl [carboxyethyl]-4,5-dihydropyrazoles under mild conditions by a conventional procedure in good yields.

\section{Experimental}

Unless otherwise indicated, all common reagents and solvents were used as obtained from commercial supplies without further purifications. ${ }^{1} \mathrm{H}$ and ${ }^{13} \mathrm{C}$ NMR spectra were recorded on a Bruker DPX $400\left(1 \mathrm{H}\right.$ at $400.13 \mathrm{MHz}$ and ${ }^{13} \mathrm{C}$ at $100.62 \mathrm{MHz}$ ) in $5 \mathrm{~mm}$ sample tubes at $298 \mathrm{~K}$ (digital resolution $\pm 0.01 \mathrm{ppm}$ ) in $\mathrm{CDCl}_{3} / \mathrm{TMS}$ solutions. Mass spectra were registered in a HP 5973 MSD connected to a HP 6890 GC and interfaced by a Pentium PC. The CG was equipped with a split-splitless injector, autosampler, cross-linked to a HP-5 capillary column ( $30 \mathrm{~m}$ length 0.32 internal diameter), and $\mathrm{He}$ was used as the carrier gas. All melting points were determined on a Reichert Thermovar apparatus. Elemental Analyses were performed on a Perkin Elmer CHN elemental analyser. The refractive index was obtained from a refractometer, using water as reference at $20^{\circ} \mathrm{C}$. X-ray data were collected on a Bruker SMART CCD diffractometer. ${ }^{23}$ The crystallographic structure was solved by direct methods (SHELXS-97). ${ }^{24}$ Refinements were carried out with the SHELXL-97 package. ${ }^{25}$ The ORTEP $^{26}$ diagram of the molecule indicating atom numbering scheme with thermal ellipsoids at $50 \%$ probability is illustrated in Figure 1.

Typical procedure for synthesis of 4,5-dihydropyrazoles 5-8

To a stirred solution of cyanoacetic acid hydrazide $(1.2 \mathrm{mmol})$ in water $(5 \mathrm{~mL})$ containing concentraded $\mathrm{HCl}$ $(0.1 \mathrm{~mL})$ at room temperature, enone 1-4 (1 mmol) was added. The mixture was stirred for 3-8 hours. The product (5-8) was extracted with $\mathrm{CH}_{2} \mathrm{Cl}_{2}(3 \times 5 \mathrm{~mL})$ and then the organic phases were dried over anhydrous $\mathrm{Na}_{2} \mathrm{SO}_{4}$ and the solvent was evaporated under reduced pressure. The 4,5-dihydropyrazoles were obtained in a pure form, without further purification. The 4,5-dihydropyrazole $\mathbf{5 f}$ was recrystallized from hexane/dichloromethane and it gaved white needles suitable for X-ray analysis.

1-Cyanoacetyl-5-hydroxy-5-trifluoromethyl-4,5-dihydro1H-pyrazole (5a)

mp 110-115 ${ }^{\circ} \mathrm{C} ;{ }^{1} \mathrm{H}$ NMR $\left(400 \mathrm{MHz}, \mathrm{CDCl}_{3}\right): \delta(J, \mathrm{~Hz})$ 3.24 (d, 1H, J 19.8, H4a), 3.42 (d, 1H, J 19.8, H4b), 3.85 (d, 1H, J 18.8, H7a), 3.88 (d, 1H, J 18.8, H7b), 7.06 (s, $1 \mathrm{H}, \mathrm{H} 3) ;{ }^{13} \mathrm{C} \mathrm{NMR}\left(100 \mathrm{MHz}, \mathrm{CDCl}_{3}\right): \delta\left(J_{\mathrm{C}-\mathrm{F}}, \mathrm{Hz}\right) 26.3$ (C7), 44.9 (C4), 91.3 (q, $\left.{ }^{2} J 35, \mathrm{C} 5\right), 112.9$ (CN), 122.6 (q, $\left.{ }^{1} \mathrm{~J} 287, \mathrm{CF}_{3}\right), 146.8(\mathrm{C} 3), 163.3(\mathrm{C}=\mathrm{O})$; MS (EI, $\left.70 \mathrm{eV}\right) \mathrm{m} / \mathrm{z}$ $\%: 221\left(\mathrm{M}^{+}, 5\right), 152$ (25), 85 (100), 69 (25). Anal. Calc. for $\mathrm{C}_{7} \mathrm{H}_{6} \mathrm{~F}_{3} \mathrm{~N}_{3} \mathrm{O}_{2}: \mathrm{C}, 38.02 ; \mathrm{H}, 2.73 ; \mathrm{N}, 19.00$. Found: C, 38.22; $\mathrm{H}, 2.84 ; \mathrm{N}, 18.78$.

1-Cyanoacetyl-5-hydroxy-3-methyl-5-trifluoromethyl-4,5dihydro-1H-pyrazole (5b)

$\mathrm{n}_{\mathrm{D}}{ }^{20}=1.4615 ;{ }^{1} \mathrm{H} \mathrm{NMR}\left(400 \mathrm{MHz}, \mathrm{CDCl}_{3}\right): \delta(\mathrm{J}, \mathrm{Hz})$ 2.08 (s, 3H, Me), 3.18 (d, 1H, $\left.{ }^{2} J 19.1, \mathrm{H} 4 \mathrm{a}\right), 3.30$ (d, 1H, ${ }^{2} J$ 19.1, H4b), 3.81 (d, 1H, J 18.8, H7a), 3.87 (d, 1H, J 18.8, $\mathrm{H} 7 \mathrm{~b}), 5.72$ (s, $1 \mathrm{H}, \mathrm{OH}) ;{ }^{13} \mathrm{C} \mathrm{NMR}\left(100 \mathrm{MHz}, \mathrm{CDCl}_{3}\right)$ : $\delta\left(J_{\mathrm{C}-\mathrm{F}}, \mathrm{Hz}\right) 14.8\left(\mathrm{CH}_{3}\right), 25.4(\mathrm{C} 7), 46.4(\mathrm{C} 4), 90.6\left(\mathrm{q},{ }^{2} \mathrm{~J} 35\right.$, C5), $112.6(\mathrm{CN}), 122.1$ (q, $\left.{ }^{1} J 287, \mathrm{CF}_{3}\right), 156.3$ (C3), 162.1 (C=O); MS (EI, $70 \mathrm{eV}) \mathrm{m} / \mathrm{z} \%: 235\left(\mathrm{M}^{+}, 10\right), 166$ (25), 99 (100), 69 (15). Anal. Calc. for $\mathrm{C}_{8} \mathrm{H}_{8} \mathrm{~F}_{3} \mathrm{~N}_{3} \mathrm{O}_{2}: \mathrm{C}, 40.86 ; \mathrm{H}$, 3.43 ; N, 17.87. Found: C, 40.49; H, 3.39; N, 17.54 .

1-Cyanoacetyl-5-hydroxy-3-ethyl-5-trifluoromethyl-4,5dihydro-1H-pyrazole $(5 \mathrm{c})$

$\mathrm{n}_{\mathrm{D}}{ }^{20}=1.4585 ;{ }^{1} \mathrm{H} \mathrm{NMR}\left(400 \mathrm{MHz}, \mathrm{CDCl}_{3}\right): \delta(J, \mathrm{~Hz}) 1.19$ (t, 3H, Me), 2.41 (q, 2H, $\mathrm{CH}_{2}$ ), 3.16 (d, 1H, ${ }^{2} J$ 19.3, H4a), 3.31 (d, 1H, $\left.{ }^{2} J 19.3, \mathrm{H} 4 \mathrm{~b}\right), 3.80$ (d, 1H, J 19.3, H7a), 3.90 (d, $1 \mathrm{H}, J 18.8, \mathrm{H} 7 \mathrm{~b}) ;{ }^{13} \mathrm{C} \mathrm{NMR}\left(100 \mathrm{MHz}, \mathrm{CDCl}_{3}\right): \delta\left(J_{\mathrm{C}-\mathrm{F}}, \mathrm{Hz}\right)$ $10.0\left(\mathrm{CH}_{3}\right), 23.3$ (C9), 26.1 (C7), $45.6(\mathrm{C} 4), 91.2$ (q, ${ }^{2} J 35$, C5), 113.2 (CN), 122.7 (q, $\left.{ }^{1} J 287, \mathrm{CF}_{3}\right), 161.4(\mathrm{C} 3), 162.9$ $(\mathrm{C}=\mathrm{O})$; MS (EI, $70 \mathrm{eV}) \mathrm{m} / \mathrm{z} \%: 249\left(\mathrm{M}^{+}, 10\right), 180(20), 113$ (100), 85 (15). Anal. Calc. for $\mathrm{C}_{9} \mathrm{H}_{10} \mathrm{~F}_{3} \mathrm{~N}_{3} \mathrm{O}_{2}: \mathrm{C}, 43.38 ; \mathrm{H}$, 4.05; N, 16.86. Found: C, 43.72; H, 3.91; N, 16.23.

1-Cyanoacetyl-5-hydroxy-3-pentyl-5-trifluoromethyl-4,5dihydro-1H-pyrazole (5e)

$\mathrm{n}_{\mathrm{D}}{ }^{20}=1.4554 ;{ }^{1} \mathrm{H} \mathrm{NMR}\left(400 \mathrm{MHz}, \mathrm{CDCl}_{3}\right): \delta(\mathrm{J}, \mathrm{Hz})$ 0.91 (t, 3H, Me), 1.29-1.36 (m, 4H, H11, H12), 1.52-1.67 (m, 2H, H10), 2.37 (t, 2H, H9), 3.14 (d, 1H, ${ }^{2} J$ 19.3, H4a), 3.30 (d, 1H, $\left.{ }^{2} J 19.3, \mathrm{H} 4 \mathrm{~b}\right), 3.80$ (d, 1H, J 18.8, H7a), 3.90 (d, $1 \mathrm{H}, J 18.8, \mathrm{H} 7 \mathrm{~b}) ;{ }^{13} \mathrm{C} \mathrm{NMR}\left(100 \mathrm{MHz}, \mathrm{CDCl}_{3}\right): \delta\left(J_{\mathrm{C}-\mathrm{F}}\right.$, Hz) 13.7 (C13), 22.1 (C12), 25.4 (C10), 26.1 (C7), 29.7 
(C11), 31.1 (C9), 45.7 (C4), $91.1\left(\mathrm{q},{ }^{2} J 35, \mathrm{C} 5\right), 113.2(\mathrm{CN})$, 122.5 (q, $\left.{ }^{1} \mathrm{~J} 287, \mathrm{CF}_{3}\right), 160.6(\mathrm{C} 3), 162.8(\mathrm{C}=\mathrm{O})$; MS (EI, $70 \mathrm{eV}) \mathrm{m} / \mathrm{z} \%: 291\left(\mathrm{M}^{+}, 10\right), 235$ (57), 192 (50), 155 (100), 85 (40), 68 (67). Anal. Calc. for $\mathrm{C}_{12} \mathrm{H}_{16} \mathrm{~F}_{3} \mathrm{~N}_{3} \mathrm{O}_{2}: \mathrm{C}, 49.49 ; \mathrm{H}$, 5.54; N, 14.43. Found: C, 49.34; H, 5.72; N, 14.12.

3,3a,4,5,6,7-Hexahydro-3-trifluoromethyl-3-hydroxy-[2,1]benzocyanoacetyl pyrazole $(\mathbf{5 f})$

mp 95-100 ${ }^{\circ} \mathrm{C} ;{ }^{1} \mathrm{H}$ NMR (400 MHz, $\left.\mathrm{CDCl}_{3}\right): \delta(J, \mathrm{~Hz})$ 1.38-1.53 (m, 2H, $\left.\mathrm{CH}_{2}\right), 1.53-1.77\left(\mathrm{~m}, 2 \mathrm{H}, \mathrm{CH}_{2}\right), 1.97-2.13$ (m, 2H, $\left.\mathrm{CH}_{2}\right), 2.24-2.34\left(\mathrm{~m}, 2 \mathrm{H}, \mathrm{CH}_{2}\right), 2.63-2.72(\mathrm{~m}, 2 \mathrm{H}$, $\mathrm{CH}_{2}$ ), 3.09 (d, 1H, ${ }^{2} J$ 6, H3a), 3.15 (d, 1H, ${ }^{2} J 6, \mathrm{CH}(\mathrm{H} 3 \mathrm{a})$ ); ${ }^{13} \mathrm{C} \mathrm{NMR}\left(100 \mathrm{MHz}, \mathrm{CDCl}_{3}\right): \delta\left(J_{\mathrm{C}-\mathrm{F}}, \mathrm{Hz}\right) 21.2(\mathrm{C} 4), 26.3$ (C9), 26.8 (C5,6), 28.3 (C7), 53.4 (C3a), 92.5 (q, ${ }^{2} J 34$, C3), $113.9(\mathrm{CN}), 123.6$ (q, $\left.{ }^{1} \mathrm{~J} 287, \mathrm{CF}_{3}\right), 163.6$ (C7a), 163.9 $(\mathrm{C}=\mathrm{O}) ; \mathrm{MS}(\mathrm{EI}, 70 \mathrm{eV}) \mathrm{m} / \mathrm{z} \%: 275\left(\mathrm{M}^{+}, 10\right), 206(80), 139$ (100), 81 (5), 68 (45). Anal. Calc. for $\mathrm{C}_{11} \mathrm{H}_{12} \mathrm{~F}_{3} \mathrm{~N}_{3} \mathrm{O}_{2}: \mathrm{C}$, 48.01; H, 4.39; N, 15.27. Found: C, 48.16; H, 4.38; N, 15.34.

1-Cyanoacetyl-5-hydroxy-3-phenyl-5-trifluoromethyl-4,5dihydro-1H-pyrazole (5g)

mp 125-130 ${ }^{\circ} \mathrm{C} ;{ }^{1} \mathrm{H}$ NMR $\left(400 \mathrm{MHz}, \mathrm{CDCl}_{3}\right): \delta(J, \mathrm{~Hz})$ 3.60 (d, 1H, $\left.{ }^{2} J 18, \mathrm{H} 4 \mathrm{a}\right), 3.76$ (d, 1H, $\left.{ }^{2} J 18, \mathrm{H} 4 \mathrm{~b}\right), 3.93$ (d, 1H, J 19, H7a), 4.03 (d, 1H, J 19, H7b), 7.43-7.72 (m, 5H, $\left.\mathrm{C}_{6} \mathrm{H}_{4}\right) ;{ }^{13} \mathrm{C} \mathrm{NMR}\left(100 \mathrm{MHz}, \mathrm{CDCl}_{3}\right): \delta\left(J_{\mathrm{C}-\mathrm{F}}, \mathrm{Hz}\right) 25.3(\mathrm{C} 7)$, 42.7 (C4), 90.9 (q, $\left.{ }^{2} J 35, \mathrm{C} 5\right), 112.2(\mathrm{CN}), 121.7$ (q, ${ }^{1} J 286$, $\left.\mathrm{CF}_{3}\right), 126.1,128.0,128.1,130.9\left(\mathrm{C}_{6} \mathrm{H}_{4}\right), 154.3(\mathrm{C} 3), 162.1$ $(\mathrm{C}=\mathrm{O})$; MS (EI, $70 \mathrm{eV}) \mathrm{m} / \mathrm{z} \%: 297\left(\mathrm{M}^{+}, 10\right), 230$ (5), 161 (100), 77 (25). Anal. Calc. for $\mathrm{C}_{13} \mathrm{H}_{10} \mathrm{~F}_{3} \mathrm{~N}_{3} \mathrm{O}_{2}: \mathrm{C}, 52.53 ; \mathrm{H}$, 3.39 ; N, 14.14. Found: C, 52.62; H, 3.38; N, 13.95.

1-Cyanoacetyl-5-hydroxy-4-methyl-5-trifluoromethyl-4,5dihydro-1H-pyrazole (5h)

$\mathrm{n}_{\mathrm{D}}{ }^{20}=1.4499 ;{ }^{1} \mathrm{H}$ NMR $\left(400 \mathrm{MHz}, \mathrm{CDCl}_{3}\right): \delta(\mathrm{J}, \mathrm{Hz})$ 1.28 (d, 3H, J 7.8, Me), 3.49 (qd, 1H, J 2, H4), 3.82 (d, $1 \mathrm{H},{ }^{2} J$ 19.4, H7a), 3.91 (d, 1H, ${ }^{2} J 19.4, \mathrm{H} 7 \mathrm{~b}$ ), 5.60 (s, 1H, $\mathrm{OH}), 6.96(\mathrm{~d}, 1 \mathrm{H}, J 2, \mathrm{H} 3) ;{ }^{13} \mathrm{C} \mathrm{NMR}\left(100 \mathrm{MHz}, \mathrm{CDCl}_{3}\right)$ : $\delta\left(J_{\mathrm{C}-\mathrm{F}}, \mathrm{Hz}\right) 9.8(\mathrm{Me}), 26.2(\mathrm{C} 7), 48.4(\mathrm{C} 4), 90.1$ (q, ${ }^{2} J 35$, C5), $113.0(\mathrm{CN}), 122.9$ (q, $\left.{ }^{1} J 287, \mathrm{CF}_{3}\right), 152.1$ (C3), 163.7 $(\mathrm{C}=\mathrm{O})$; MS (EI, $70 \mathrm{eV}) \mathrm{m} / \mathrm{z} \%: 235\left(\mathrm{M}^{+}, 5\right), 166(20), 99$ (100), 69 (15). Anal. Calc. for $\mathrm{C}_{8} \mathrm{H}_{8} \mathrm{~F}_{3} \mathrm{~N}_{3} \mathrm{O}_{2}: \mathrm{C}, 40.86 ; \mathrm{H}$, 3.43 ; N, 17.87. Found: C, 40.96; H, 3.40; N, 17.70.

1-Cyanoacetyl-5-hydroxy-5-trichloromethyl-4,5-dihydro1H-pyrazole (6a)

mp 109-112 ${ }^{\circ} \mathrm{C} ;{ }^{1} \mathrm{H}$ NMR (400 MHz, $\left.\mathrm{CDCl}_{3}\right): \delta(J, \mathrm{~Hz})$ 3.38 (d, 1H, $\left.{ }^{2} J 19.8, \mathrm{H} 4 \mathrm{a}\right), 3.70$ (d, 1H, $\left.{ }^{2} J 19.8, \mathrm{H} 4 \mathrm{~b}\right), 3.90$ (s, 2H, H7), $6.50(\mathrm{~s}, 1 \mathrm{H}, \mathrm{OH}), 7.16(\mathrm{~s}, 1 \mathrm{H}, \mathrm{H} 3) ;{ }^{13} \mathrm{C}$ NMR (100 MHz, DMSO-d ): $\delta 23.9$ (C7), 48.9 (C4), 97.6 (C5), $102.9\left(\mathrm{CCl}_{3}\right), 115.3(\mathrm{CN}), 152.1(\mathrm{C} 3), 160.8(\mathrm{C}=\mathrm{O})$; MS (EI, $70 \mathrm{eV}) \mathrm{m} / \mathrm{z} \%: 152\left(\mathrm{M}^{+}-\mathrm{CCl}_{3}, 5\right), 117$ (4), 99 (69), 71 (100). Anal. Calc. for $\mathrm{C}_{7} \mathrm{H}_{6} \mathrm{Cl}_{3} \mathrm{~N}_{3} \mathrm{O}_{2}: \mathrm{C}, 31.08 ; \mathrm{H}, 2.24 ; \mathrm{N}$, 15.53. Found: C, 31.05; H, 2.11; N, 15.47.

1-Cyanoacetyl-5-hydroxy-3-methyl-5-trichloromethyl-4,5dihydro-1H-pyrazole (6b)

mp 132-137 ${ }^{\circ} \mathrm{C} ;{ }^{1} \mathrm{H}$ NMR (400 MHz, $\left.\mathrm{CDCl}_{3}\right): \delta(J, \mathrm{~Hz})$ 2.10 (s, 3H, Me), 3.32 (d, 1H, $\left.{ }^{2} J 19.0, \mathrm{H} 4 \mathrm{a}\right), 3.54$ (d, 1H, ${ }^{2} J$ 19.0, H4b), 3.83 (d, 1H, ${ }^{2} J$ 19.0, H7a), 3.88 (d, 1H, ${ }^{2} J$ 19.0, $\mathrm{H} 7 \mathrm{~b}), 6.64$ (s, 1H, OH); $\left.{ }^{13} \mathrm{C} \mathrm{NMR} \mathrm{(100} \mathrm{MHz,} \mathrm{CDCl}_{3}\right): \delta$ 15.7 (Me), 26.8 (C7), 50.1 (C4), 101.5 (C5), $106.9\left(\mathrm{CCl}_{3}\right)$, $113.3(\mathrm{CN}), 159.0$ (C3), $164.2(\mathrm{C}=\mathrm{O})$; MS (EI, $70 \mathrm{eV}) \mathrm{m} / \mathrm{z}$ \%: $166\left(\mathrm{M}^{+}-\mathrm{CCl}_{3}, 25\right), 99$ (100), 83 (12), 68 (25). Anal. Calc. for $\mathrm{C}_{8} \mathrm{H}_{8} \mathrm{Cl}_{3} \mathrm{~N}_{3} \mathrm{O}_{2}$ : C, 33.77; $\mathrm{H}, 2.83 ; \mathrm{N}, 14.77$. Found: C, 34.15; H, 3.00; N, 14.51 .

1-Cyanoacetyl-5-hydroxy-3-ethyl-5-trichloromethyl-4,5dihydro-1H-pyrazole (6c)

mp 98-101 ${ }^{\circ} \mathrm{C} ;{ }^{1} \mathrm{H}$ NMR (400 MHz, $\left.\mathrm{CDCl}_{3}\right): \delta(J, \mathrm{~Hz})$ 1.19 (t, 3H, Me), 2.41 (q, 2H, $\mathrm{CH}_{2}$ ), 3.15 (d, 1H, ${ }^{2} J$ 19.3, H4a), 3.31 (d, 1H, ${ }^{2} J 19.3, \mathrm{H} 4 \mathrm{~b}$ ), 3.79 (d, 1H, ${ }^{2} J 19.0, \mathrm{H} 7 \mathrm{a}$ ), 3.90 (d, 1H, ${ }^{2} J$ 19.0, H7b); ${ }^{13} \mathrm{C}$ NMR (100 MHz, $\left.\mathrm{CDCl}_{3}\right)$ : $\delta 10.2$ (C10), 23.7 (C9), 27.1 (C7), 48.9 (C4), 101.7 (C5), $103.0\left(\mathrm{CCl}_{3}\right), 113.6(\mathrm{CN}), 163.6(\mathrm{C} 3), 164.6(\mathrm{C}=\mathrm{O})$; $\mathrm{MS}(\mathrm{EI}$, $70 \mathrm{eV}) \mathrm{m} / \mathrm{z} \%: 181\left(\mathrm{MH}^{+}-\mathrm{CCl}_{3}, 17\right), 125$ (60), 113 (100), 97 (76), 63 (71). Anal. Calc. for $\mathrm{C}_{9} \mathrm{H}_{10} \mathrm{Cl}_{3} \mathrm{~N}_{3} \mathrm{O}_{2}: \mathrm{C}, 36.21 ; \mathrm{H}$, 3.38 ; N, 14.07. Found: C, 36.43; H, 3.33; N, 14.20.

1-Cyanoacetyl-5-hydroxy-3-propyl-5-trichloromethyl-4,5dihydro-1H-pyrazole (6d)

$\mathrm{n}_{\mathrm{D}}{ }^{20}=1.3890 ;{ }^{1} \mathrm{H}$ NMR $\left(400 \mathrm{MHz}, \mathrm{CDCl}_{3}\right): \delta(J, \mathrm{~Hz})$ 1.00 (t, 3H, Me), 1.56-1.77 (m, 2H, H10), 2.37 (t, 2H, H9), 3.29 (d, 1H, $\left.{ }^{2} J 19.1, \mathrm{H} 4 \mathrm{a}\right), 3.56$ (d, 1H, $\left.{ }^{2} J 19.1, \mathrm{H} 4 \mathrm{~b}\right), 3.87$ (s, 2H, H7), 6.65 (s, 1H, OH); $\left.{ }^{13} \mathrm{C} \mathrm{NMR} \mathrm{(100} \mathrm{MHz,} \mathrm{DMSO-d}\right)$ : $\delta 15.5$ (C11), 19.2 (C10), 26.7 (C7), 31.8 (C9), 48.8 (C4), 100.0 (C5), $101.2\left(\mathrm{CCl}_{3}\right), 113.2(\mathrm{CN}), 162.2(\mathrm{C} 3), 164.2$ $(\mathrm{C}=\mathrm{O})$; $\mathrm{MS}(\mathrm{EI}, 70 \mathrm{eV}) \mathrm{m} / \mathrm{z} \%: 194\left(\mathrm{M}^{+}-\mathrm{CCl}_{3}, 37\right), 167$ (5), 113 (100), 71 (30). Anal. Calc. for $\mathrm{C}_{10} \mathrm{H}_{12} \mathrm{Cl}_{3} \mathrm{~N}_{3} \mathrm{O}_{2}$ : C, 38.43; H, 3.87; N, 13.44. Found: C, 38.69; H, 3.63; N, 13.43 .

1-Cyanoacetyl-5-hydroxy-3-methyl-5,5-dichloromethyl4,5-dihydro-1H-pyrazole (7b)

$\mathrm{n}_{\mathrm{D}}{ }^{20}=1.5250 ;{ }^{1} \mathrm{H}$ NMR $\left(400 \mathrm{MHz}, \mathrm{CDCl}_{3}\right): \delta(\mathrm{J}, \mathrm{Hz})$ 2.10 (s, 3H, Me), 3.04 (d, 1H, $\left.{ }^{2} J 19.1 \mathrm{~Hz}, \mathrm{H} 4 \mathrm{a}\right), 3.53$ (d, 
1H, ${ }^{2} J$ 19.1, H4b), 3.81 (s, 2H, H7), 4.75 (s, 1H, OH), $6.51\left(\mathrm{~s}, 1 \mathrm{H}, \mathrm{CHCl}_{2}\right) ;{ }^{13} \mathrm{C} \mathrm{NMR}\left(100 \mathrm{MHz}, \mathrm{CDCl}_{3}\right): \delta 15.8$ (Me), 25.7 (C7), 46.6 (C4), 72.3 (C5), $96.0\left(\mathrm{CHCl}_{2}\right), 113.4$ (CN), 157.7 (C3) $161.6(\mathrm{C}=\mathrm{O})$; MS (EI, $70 \mathrm{eV}) \mathrm{m} / \mathrm{z} \%$ : $250\left(\mathrm{MH}^{+}, 1\right), 166$ (68), 99 (100), 68 (18). Anal. Calc. for $\mathrm{C}_{8} \mathrm{H}_{9} \mathrm{C}_{12} \mathrm{~N}_{3} \mathrm{O}_{2}: \mathrm{C}, 38.42 ; \mathrm{H}, 3.63 ; \mathrm{N}, 16.80$. Found: C, 38.02; $\mathrm{H}, 3.39$; N, 16.51 .

1-Cyanoacetyl-5-hydroxy-3-methyl-5-ethoxy-4,5-dihydro1 H-pyrazole $(\mathbf{8 b})$

$\mathrm{n}_{\mathrm{D}}{ }^{20}=1.4169 ;{ }^{1} \mathrm{H}$ NMR $\left(400 \mathrm{MHz}, \mathrm{CDCl}_{3}\right): \delta(J, \mathrm{~Hz})$ 1.31 (t, 3H, Me), 2.10 (s, 3H, Me), 3.00 (d, 1H, ${ }^{2} J 18.8$, H4a), 3.26 (d, 1H, $\left.{ }^{2} J 18.8, \mathrm{H} 4 \mathrm{~b}\right), 3.75$ (d, 1H, $\left.{ }^{2} J 18.6, \mathrm{H} 7 \mathrm{a}\right)$, $3.82\left(\mathrm{~d}, 1 \mathrm{H},{ }^{2} \mathrm{~J} 18.6, \mathrm{H} 7 \mathrm{~b}\right), 4.32\left(\mathrm{q}, 2 \mathrm{H}, \mathrm{CH}_{2}\right) ;{ }^{13} \mathrm{C} \mathrm{NMR}$ (100 MHz, $\left.\mathrm{CDCl}_{3}\right)$ : $\delta 13.9(\mathrm{C} 12), 15.6(\mathrm{C} 9), 25.1$ (C7), 49.7 (C4), $63.4\left(\mathrm{CH}_{2}\right), 87.8(\mathrm{C} 5), 113.7(\mathrm{CN}), 156.1(\mathrm{C} 3), 159.8$ (C=O), 169.1 (C6); MS (EI, $70 \mathrm{eV}) \mathrm{m} / \mathrm{z} \%: 166\left(\mathrm{M}^{+}-\mathrm{CO}_{2} \mathrm{Et}\right.$, 30), 99 (100). Anal. Calc. for $\mathrm{C}_{10} \mathrm{H}_{13} \mathrm{~N}_{3} \mathrm{O}_{4}: \mathrm{C}, 50.21 ; \mathrm{H}, 5.48$; N, 17.57. Found: C, 49.86; H, 5.15; N, 17.23.

\section{3-Methyl-5-trifluoromethyl-1H-pyrazole (9b)}

mp 89-90 ${ }^{\circ} \mathrm{C} ;{ }^{1} \mathrm{H}$ NMR $\left(400 \mathrm{MHz}, \mathrm{CDCl}_{3}\right): \delta 2.37$ (s, $3 \mathrm{H}, \mathrm{Me}), 6.32$ (s, 1H, H4); ${ }^{13} \mathrm{C}$ NMR (100 MHz, $\mathrm{CDCl}_{3}$ ): $\delta\left(J_{\mathrm{C}-\mathrm{F}}, \mathrm{Hz}\right) 9.5(\mathrm{Me}), 102.5(\mathrm{C} 4), 121.6\left(\mathrm{q},{ }^{1} J 286, \mathrm{CF}_{3}\right)$, 139.7 (C3), 142.6 (q, ${ }^{2} J$ 34, C5); MS (EI, 70 eV) $\mathrm{m} / \mathrm{z} \%$ : 150 (100), 131 (45), 101 (40), 81 (40). Anal. Calc. for $\mathrm{C}_{5} \mathrm{H}_{5} \mathrm{~F}_{3} \mathrm{~N}_{2}: \mathrm{C}, 40.01 ; \mathrm{H}, 3.36 ; \mathrm{N}, 18.66$. Found: $\mathrm{C}, 40.36$; $\mathrm{H}, 3.15 ; \mathrm{N}, 18.33$.

Procedure for synthesis of 3-dimethylamino-2-(5-hydroxy3-methyl-5-trifluoromethyl-4,5-dihydro-1H-pyrazole-1carbonyl)acrylonitrile (10b)

A mixture of 4,5-dihydropyrazole $\mathbf{5 b}(1 \mathrm{mmol})$ and dimethylformamide dimethyl acetal $(1.2 \mathrm{mmol})$ was stirred for 2 hours at $50{ }^{\circ} \mathrm{C}$. After completion of the reaction, the excess of DMFDMA was removed under reduced pressure. This product was obtained in a pure form, without further purification.

3-Dimethylamino-2-(5-hydroxy-3-methyl-5-trifluoromethyl-4,5-dihydro-1H-pyrazole-1-carbonyl)acrylonitrile (10b)

mp 170-173 ${ }^{\circ} \mathrm{C} ;{ }^{1} \mathrm{H}$ NMR (400 MHz, $\left.\mathrm{CDCl}_{3}\right): \delta(J, \mathrm{~Hz})$ 2.09 (s, 3H, Me), 3.02 (d, 2H, ${ }^{2} J$ 19.0, H4a), 3.24 (d, 2H, ${ }^{2} J$ 19.0, H4b), 3.23 (s, 3H, NMe), 3.45 (s, 3H, NMe), 7.77 (s, 1H, H9); ${ }^{13} \mathrm{C} \mathrm{NMR}\left(100 \mathrm{MHz}, \mathrm{CDCl}_{3}\right): \delta\left(J_{\mathrm{C}-\mathrm{F}}, \mathrm{Hz}\right) 14.8$ (Me), 37.6 (C4), 45.9 (C10), 47.2 (C11), 72.3 (C7), 91.3 (q, $\left.{ }^{2} J 34, \mathrm{C} 5\right), 117.1$ (q, $\left.{ }^{1} J 286, \mathrm{CF}_{3}\right), 151.9$ (C9), 157.7 (C4), $167.8(\mathrm{C}=\mathrm{O})$; MS (EI, $70 \mathrm{eV}) \mathrm{m} / \mathrm{z} \%: 290\left(\mathrm{M}^{+}, 5\right), 179$ (3), 123 (100), 80 (10). Anal. Calc. for $\mathrm{C}_{11} \mathrm{H}_{13} \mathrm{~F}_{3} \mathrm{~N}_{4} \mathrm{O}_{2}$ : C, 45.52; H, 4.51; N, 19.30. Found: C, 45.22; H, 4.17; N, 19.01 .

\section{Acknowledgments}

The authors thank the Conselho Nacional de Desenvolvimento Científico e Tecnológico (CNPq), Coordenação de Aperfeiçoamento de Pessoal de Nível Superior (CAPES) and Fundação de Apoio à Pesquisa do Estado do Rio Grande do Sul (FAPERGS) for financial support. The fellowships from $\mathrm{CNPq}$ and CAPES are also acknowledged.

\section{References}

1. Bondock, S.; Tarhoni, A. E.-G.; Fadda, A. A.; Arkivoc 2006, ix, 113.

2. Gmaj, J.; Sosnowski, C.; Zaremba, Z.; Mrowinski, B.; Polish Patent 88, 272649 1990. (CA 114:64264)

3. Elgemeie, G. E. H.; El-Ezbawy, S. R.; Ramiz, M. M.; Mansour, O. A.; Org. Prep. Proced. Int. 1991, 23, 645.

4. Gutcait, A.; Belyakov, S. V.; Gudriniece, E.; Bleidelis, J.; Mishnev, A. F.; Kramina, M.; Kimijas Serija 1986, 5 , 607.

5. Elmoghayar, M. R. H.; Elagamey, A. G. A.; Nasr, M. Y. S.; Sallam, M. M. M.; J. Heterocycl. Chem. 1984, 21, 1885.

6. Gorolets, N. Y.; Yousefi, B. H.; Belaj, F.; Kappe, C. O.; Tetrahedron 2004, 60, 8633.

7. Gewald, V. K.; Hofmann, I.; J. Prakt. Chem. 1969, 311, 702.

8. Drummond, J. T.; Johnson, G.; J. Heterocycl. Chem. 1988, 25 , 1123.

9. El-Wassimy, M. T. M.; Sohag Pure Appl. Sci. Bull. 1991, 7, 1.

10. Balicki, R.; Kaczmarek, L.; Nantka-Namirski, P.; Acta Pol. Pharm. 1976, 33, 289.

11. Colla, A.; Clar, G.; Martins, M. A. P.; Krimmer, S.; Fischer, P.; Synthesis 1991, 483.

12. Martins, M. A. P.; Cunico, W.; Pereira, C. M. P.; Sinhorin, A. P.; Flores, A. F. C.; Bonacorso, H. G.; Zanatta N.; Curr. Org. Chem. 2004, 1, 391;

13. Druzhinin, S. V.; Balenkova, E. S.; Nenajdenko, V. G.; Tetrahedron 2007, 63, 7753.

14. Katritzky, A. R.; Rees, C. W.; Scriven, E. F. V.; Comprehensive Heterocyclic Chemistry II, Vol. 3; Elsevier Science: New York, 1996.

15. Nenajdenko, V. G.; Sanin, A. V.; Balenkova, E. S.; Molecules $\mathbf{1 9 9 7 ,} 2,186$.

16. Tietze, F.; Meier, H.; Voss, E.; Synthesis 1988, 274.

17. Kappe, O. C.; Gorobets, N.Yu.; Yousefi, B. H.; Belaje, F.; Tetrahedron 2004, 60, 8633. 
18. Dewar, M. J. S.; Zoebisch, E. G.; Healey, E. F.; Stewart, J. J. P.; J. Am. Chem. Soc. 1985, 107, 3902; HyperChem; Hypercube, Inc.: Waterloo, Ontario, Canada, 2002.

19. Martins; M. A. P.; Flores, A. F. C.; Freitag, R. A.; Zanatta, N.; Hörner, M.; Bortoluzzi, A. J.; Spectrosc. Lett. 1997, 30, 661.

20. Crystallographic data for structure $\mathbf{5 f}$, reported in this paper, have been deposited with the Cambridge Crystallographic Data Center (CCDC 660730). Copies of the data can be obtained, free of charge, on application to CCDC 12 Union Road, Cambridge CB2 1EZ, UK (Fax: +44-1223-336033 or e-mail: deposit@ ccdc.cam.ac.uk).

21. Vdovenko, S. I.; Gerus, I. I.;Wójcik, J.; J. Phys. Org. Chem. 2001, 14, 533

22. Katritzky, A. R.; Rees, C. W.; Comprehensive Heterocyclic Chemistry, Vol. 5; Pergamon Press: Oxford, 1984.
23. Bruker (2006), APEX2 (Version 2.1), COSMO (Version 1.56), BIS (Version 2.0.1.9), SAINT (Version 7.3A) and SADABS (Version 2004/1) \& XPREP (Version 2005/4), Bruker AXS Inc.: Madison, Wisconsin, USA.

24. Sheldrick, G. M.; SHELXS-97, Program for Crystal Structure Solution, University of Göttingen: Germany, 1997.

25. Sheldrick, G. M.; SHELXL-97, Program for Crystal Structure Refinement, University of Göttingen: Germany, 1997.

26. Farrugia, L. J.; J. Appl. Cryst. 1997, 30, 565.

Received: December 16, 2007 Web Release Date: August 22, 2008 